\title{
Analysis of Accounting Information System For Raw Material in PT Jadimas-Gresik
}

\author{
Zeni Rusmawati ${ }^{1}$, Fitri Nuraini ${ }^{2}$, Rieska Maharani ${ }^{3}$ \\ $\left\{\right.$ u_zeni@yahoo.co.id ${ }^{1}$ \} \\ Faculty of Economics and Business, University of Muhammadiyah Surabaya ${ }^{1,2,3}$
}

\begin{abstract}
The development of technology and information requires companies faced with intense business competition, so the company is expected to survive better than its competitors. Therefore, through Accounting Information System at PT Jadimas expected to support good internal control, to be able to save the company's assets. A critical part of supporting the company's production is raw material inventory. Therefore, it is essential for companies to know how the implementation of SIA raw material inventory in support of internal control in the company. The research method used is descriptive qualitative. The results showed that the procedures and accounting information system raw material inventory that has been made is good, but can not be applied maximally due to the constraints of human resources so that the system has been made not able to apply internal control in all elements.
\end{abstract}

Keywords: Accounting Information System, Purchase of Raw Material, Internal Control

\section{Introduction}

The era of information technology resulted in increasing competition between companies, both companies engaged in services, trade, and industry. Of course, this competition is intended to increase sales turnover that affects the company's performance is profit. In increasing the sales turnover of course also cannot be separated from finished goods inventory sold. According to [1] inventories are (a) assets available for sale in the ordinary course of business, (a) assets in the production process and or in transit, (c) in the form of materials or equipment used in the production or service process. Inventory owned by the company is different depending on the type of company. Inventory owned by a service company in the form of equipment because the service company does not sell goods. Inventory owned by a trading company in the form of merchandise inventory, which is meant merchandise is goods purchased for resale. Moreover, inventories owned by industrial companies in the form of raw material inventory, supporting materials, in-process products, and finished products.

Most of the companies in Indonesia are industrial companies; companies in carrying out their business activities require raw materials as the main ingredient in the production process. Raw materials are materials that are processed to produce the product. Each industry company varies the raw materials used; for example, the furniture company consists of wood raw materials, plywood, nails, sandpaper, putty, and so forth. Moreover, if there is a shortage of raw materials available, then it can lead to inhibition of production processes that can reduce sales turnover. 
Efforts made to provide sufficient raw materials for the production process of course taken with the purchase of raw materials. Purchase of raw materials to run effectively and efficiently, it must pay attention to the implementation of a reasonable purchasing system tailored to the conditions of each company.

According to [2] system is a series of two or more interconnected components and interact to achieve goals. The accounting system is an organization of forms, records, and reports that are coordinated in such a way as to provide the financial information needed by management to facilitate the management of the company [3]. Moreover, the procedure according to [3] is a sequence of administrative activities, usually involving several people in one or more departments, created to ensure the uniform handling of repeated corporate transactions. Procedures are part of a system.

Internal control systems include organizational structures, methods, and measures that are coordinated to safeguard organizational assets, check the accuracy and reliability of accounting data, encourage efficiency and encourage compliance with management policies - elements of the internal control system as an element inherent in the various accounting systems to be designed.

The accounting system for purchasing raw materials is designed to deal with issues related to raw material purchase transactions. Usually, the problems faced by industrial companies related to raw materials and production processes, namely the smoothness of the production process. The availability of sufficient raw materials is a factor in determining the smoothness of the production process. Moreover, for raw materials available enough for the production process, the purchase of raw materials is made correctly, among others, from the amount of inventory demanded, the arrival time and the price of raw materials obtained. Quality of production is another problem that is often faced by the industry. The quality of the production depends on the quality of the raw materials used so that the production can be qualified then the selection of raw materials used must be by the standards set by the company.

Internal control of the company in the accounting system and purchasing procedures related to the elements in internal control that are separating the functional responsibilities explicitly, the authorization system and recording procedures, healthy practices and employees of appropriate quality with responsibility.

\section{$2 \quad$ Literature Review}

\subsection{Accounting information system}

According to [2] system is a series of two or more interconnected components and interact to achieve goals. The system consists of a network of procedures; the procedure is a sequence of administrative activities. An accounting information system is an organization of forms, records, and reports coordinated in such a way as to provide the financial information needed by management to facilitate the management of the company [3].

\subsection{Stock}

Inventory is one of the most important assets for an entity for retail, manufacturing, service, or other entities [4]. The inventory classification between one entity and another entity may vary. Either trading entities retail or wholesale companies' record inventories as merchandise inventories. For manufacturing entities, inventory classifications are relatively more diverse. 
For example, a manufacturing company that produces automotive parts by purchasing product materials, and selling the parts to dealers. For such a company, the inventory includes as finished goods inventory which is ready for sale; the finished goods inventory is in the intermediate goods and the supply of raw materials, which are the materials or equipment to be used in the production process [4].

\subsection{Raw material}

According to [1] raw materials are materials that are processed to produce the product. Raw materials are recorded based on inventory cost. PSAK No.14 of 2009 explains, "inventory costs shall include all purchases and other costs incurred in order for raw materials to be in a readyto-use condition".

\subsection{Accounting information systems purchases}

According to [3] they are purchasing accounting system used in the company for the procurement of goods required by the company. Purchase transactions can be classified into two, i.e., local and import purchases. The related functions in purchasing accounting system are (a) warehouse function, (b) purchasing function, (c) acceptance function, (d) accounting function. The internal control elements in the purchasing accounting system are designed to achieve the principal objectives of the following accounting internal controls: safeguarding corporate assets (liabilities) and liabilities (trading payables or cash outgoings to be paid), ensuring the accuracy and reliability of accounting data (debt and inventory).

\subsection{Internal Control}

According to [2] internal control is a process run to assure that the following control objectives have been achieved in the three elements of internal control (Organization, Authorization, and sound practice)

Internal control is a process because it spreads throughout the company's operating activities and is an integral part of management activities. Internal controls provide sufficient guarantees-a thorough guarantee that is difficult to achieve and too expensive. Also, internal controls have inherent limitations, such as weaknesses to errors and simple mistakes, wrong judgment and decision making, management's waivers and collusion.

\section{Research Method}

This research uses a research method exposed facto method, aims to reveal data because of the occurrence of a symptom or problem dealing with data or facts that had occurred before the study was conducted [5]. Researchers use this method because the data obtained, which is then processed, is the data of the past. The research approach used is a qualitative descriptive approach that is research approach, which aims to process and analyze data in the form of documents related to the purchase of raw materials, such as SOP, Purchase Request, Purchase Order, Goods Receipt Report (LPB), and so forth.

This research was conducted at PT. Jadimas Surabaya. The object of study in this research is the function or related parts, documents used and accounting records used in accounting system purchases of raw materials at PT. Jadimas. 
Data collection techniques use documentation and interviews. Data in the form of documents related to the existing purchasing accounting system in the company, such as letter of purchase request, letter or purchase order, goods receipt report, purchasing journal, stock card, stock card warehouse, and mail.

Analytical techniques using descriptive qualitative, i.e., analysis techniques in the form of describing or reveal the characteristics of variables - the variables that become the focus of the researcher. The data will compare the theory and facts of the procedure descriptively from the accounting system and procedures for purchasing raw materials of PT. Jadimas.

\section{$4 \quad$ Result and Discussion}

\subsection{Procedure}

Flow Chart of Accounting System Purchase (flowchart)

a. Parts of Warehouse

1. Make a two-page purchase order (SPP) based on information on the reorder point stated on the warehouse card.

2. Send the first purchase request letter (Purchase Requisition) to the purchasing department.

3. Receive a Purchase Order from the purchasing department as a notification of the order that has been executed.

4. Archive letter of purchase order into the archive according to the serial number.

5. I am receiving reports on receipt of goods from the reception.

6. Record report receipt of goods in warehouse card.

b. Purchasing department

1. Receiving Purchase Requisition from the warehouse.

2. Creating a price offer letter sent to the supplier

3. Receive offer letter from supplier price.

4. Make price comparisons by price quotes received from suppliers.

5. I am selecting suppliers based on price quotes.

6. Create a letter of a purchase order for the selected supplier.

7. Distribute letter of purchase order as follows: (a) First sheet:Sent to the selected supplier; (b) The second sheet: Shipped to the receiving department to authorize the section to receive goods from suppliers listed in the document; (c) Third sheet: sent to the debt to inform that the company will one day have an obligation to the supplier listed in the document.

8. It is receiving acceptance report of the first sheet of goods from the admissions department. Record the date of receipt of this item in the purchase order letter of the sixth and seventh sheet. It is moving a letter of the purchase order that has been received.

9. Submit reports on receipt of goods to the debt.

10. Receive invoice from the supplier.

11. Receive invoices from suppliers to determine whether the supplier has been correct in stating the price, quantity and have met the terms of purchase listed in the purchase order letter.

c. Reception section.

1. Receive a letter of purchase order of the second sheet from the purchasing department. 
2. You are receiving goods accompanied by a letter of introduction from the supplier.

3. I am checking the goods received, both on the quantity and on quality of goods, based on the information in the purchase order letter third sheet.

4. Make a report of acceptance of three sheets.

5. Distribute receipt reports as follows: first sheet: Sent to the debt through the purchasing department. The second sheet: Sent to the warehouse along with the goods in question. Third sheet: Stored in the archive by a serial number of goods acceptance report enclosed with letter of purchase order of third sheet and letter of introduction from the supplier.

d. Debt Section

1. Receiving a letter of purchase order of the fourth sheet from the purchasing department.

2. I am receiving an acceptance report of the first sheet of goods from the receipt of goods via the purchasing department.

3. Receive invoices from suppliers via the purchasing department.

4. Compare supplier invoices, goods receipt reports and purchase order documents, to determine whether bills received from suppliers are goods already received by the company and for goods ordered by the company.

5. Make proof of cash out as much as three sheets.

6. Record the cash out proof into the cash out cash proof register.

7. Send proof of cash out to the stock card and charge card.

8. Archive cash proof out of the first and third sheets together with supporting documents into the unpaid cash out cash records according to the invoice due date.

e. Inventory card section

1. Receiving proof of cash out the second sheet of debt section.

2. Record the items purchased in the stock card.

3. I am storing cash proof in the archive according to the serial number.

Table 1. Internal Control Analysis

\begin{tabular}{ll}
\hline Intern Control Unsure & \multicolumn{1}{c}{ Activity Analysis } \\
\hline Organization & $\begin{array}{l}\text { PT Jadimas has made proper accounting procedures and accounting } \\
\text { systems, but there is no clear division of tasks between each part, so } \\
\text { sometimes the purchases take over the cashier and receipt of goods } \\
\text { and debt. }\end{array}$ \\
& $\begin{array}{l}\text { Each file is authorized, but its authorization is sometimes not from the } \\
\text { holder of authority and responsibility, because the organization's } \\
\text { Authorization }\end{array}$ \\
& $\begin{array}{l}\text { Accounting Information System inventory of raw materials have been } \\
\text { applied in PT Jadimas, but human resources that operate not trained }\end{array}$ \\
Good practice & so that slow the running of existing systems \\
\hline
\end{tabular}

This research showed that the level of education and training have positive and significant, both simultaneously and partially on the performance [6]. Research findings indicate that indeed training and career development has an impact on their performance [7], [8]. The result of the study is on the job training has a significant effect on employee's performance [9]. 


\section{Conclusion}

Conclusion base dons their result of research procedure and accounting information system of purchasing of raw materials that have been made right, but not yet can be applied maximally because of its human resource constraint. So that the system has been made not able to apply internal control in all elements (authorization, organization and healthy practice). PT Jadi Mas needs to provide training for employees involved with the operation of accounting information systems so that it can run well and able to support the company's internal control system.

\section{Reference}

[1] J. Y. Erhans, Akuntansi Berdasarkan Prinsip Akuntansi Indonesia-Dagang dan Industri. Jakarta: PT. Ercontara Rajawali, 2016.

[2] M. B. Romney and P. J. Steinbart, Sistem Informasi Akuntansi (Accounting Information Systems). Jakarta: Salemba Empat, 2015.

[3] Mulyadi, Sistem Akuntansi. Jakarta: Salemba Empat, 2016.

[4] D. Martani, Akuntansi Keuangan Menengah Berbasis PSAK, 2nd ed. Jakarta: Salemba Empat, 2016.

[5] Sugiyono, Metode Penelitian Pendidikan: Pendekatan Kuantitatif, Kualitatif, dan RND. Bandung: Alfabeta, 2015.

[6] R. Mamahit, 'Tingkat Pendidikan, Pelatihan Dan Kepuasan Kerja Pengaruhnya Terhadap Kinerja Pegawai Di Badan Penanggulangan Bencana Provinsi Sulawesi Utara', J. Emba, vol. 1, no. 4, pp. 936-945, 2013.

[7] B. C. Charity, 'Job Rotation: An Examination Of Its Effect On Employee Performance At Kcb Branches In The North Rift Region, Kenya', Int. J. Adv. Res. Manag. Manag. Soc. Sci., vol. 4, no. 5, pp. 84-93, 2015.

[8] B. C. Charity, 'Effect of Training and Career Development on Employee Performance: a Case of Kcb Branches in the North Rift Region, Kenya', Int. J. Adv. Res. Manag. Soc. Sci., vol. 4, no. 5, pp. 38-49, 2015.

[9] Y. R. Nababan, H. N. Tawas, and J. Uhing, 'Pengaruh pendidikan dan pelatihan kerja terhadap kinerja karyawan pt.pln (persero) area manado influence of education and job training on employees performance at pt. pln (persero) area manado', J. Emba, vol. 4, no. 3, p. 9, 2016. 